\title{
Utilizing Music in Sport and Exercise at Elementary School in Indonesia
}

\author{
Ardipal $^{1}$ \\ ${ }^{1}$ Universitas Negeri Padang, Indonesia \\ Correspondence: Ardipal, Universitas Negeri Padang, Jln. Prof. Dr. Hamka - Air Tawar, Padang, Sumatera Barat, \\ Indonesia. E-mail: ardipalarly@ymail.com
}

Received: February 12, 2014

Accepted: February 20, 2014 Online Published: February 28, 2014

doi:10.5539/ass.v10n5p118

URL: http://dx.doi.org/10.5539/ass.v10n5p118

\begin{abstract}
Some researchers have mentioned that music can be used in sports. The first research was published in 1999 about music in sports. It shows that music can decrease exhaustion in athletes. Most of the research is related to the influence of music toward sports and exercises, and is conducted on professional atheletes. However, it is still rarely used or researched for the early stages of chilhood education. This article intends to explain the use of music in sports and exercises in elementary schools in Indonesia. It studies early childhood characteristics and the music that has been used in sports. It also highlights some of music that can be used for the purpose of stimulating the students to do given exercises. This article is intended for the use of coaches and physical education teachers.
\end{abstract}

Keywords: sport, music, sport teacher, elementary school

\section{Introduction}

Education in Primary Schools is an education that aims to develop the full potential that the students have. Education serves to help the psychological growth and development of students that is done outside the family environment. Education today not only serves to provide learning experiences to students, but more to the developments to optimize brain function, physical, psychological, and social development. Therefore, early childhood education should also include psychosocial stimulation and the whole process should not be limited to basic learning processes.

Based on the growth and the abilities of the students at an early age, the elementary school education only aim for three goals, they are: (1) establish and develop a spirit of exploration, (2) establish and develop the creative spirit, and (3) establish and develop the integral characters. Moreover, based on the National Education System, it is stated that education aims to develop the potential of learners in the form of faith, piety and healthy living, by introducing independent activities, value of beauty, the role of democracy, social roles, national attributes and natural environment through fun activities. Thus, everything is still introduceed by the means of fun activities.

One of the activities that are currently applied in elementary schools is physical education. Unfortunately, some students tend to not be involved during physical exercises. In connection with the implementation of Curriculum 2013 in Indonesia, which integrates lessons in several themes, it is possible to develop the elementary school students' physical health through a combination of pleasurable activities like music/singing and physical education. Musical activities associated with the expression of human feelings are realized through common and folk songs that is combined with music and arts as an aid in performance. Music/singing emphasizes the cultivation of values are realized through harmonious tone.

Currently, music has been used by people who often exercise, athletes, some fitness centers and it has become commonplace. Some researchers have also prove that listening to music will increase health condition (Karageorghis \& Terry, 1997). Music can significantly influence performance by increasing exercise intensity thus, improving endurance (Karageorghis, Terry, Lane, Priest, Bishop, \& Lee, 2011). However, it is still rarely studied in the early stages of childhood education. The nature of children that are more inclined to fun activities, needs a fun sport and/or activity which can be done by combining music/singing activities and physical exercise. However, music selection is often based on intuition rather than empirical evidence. Therefore, sport and exercise can be the focus for an empirical research in prescribing music for physical activity. The purpose of this 
article is to show how to use music in sport and exercise at elementary school in Indonesia.

\section{Review of Related Theories}

In order to develop students effectively, of course, we need to know the early childhood characteristics. Children's growth is rapid between the ages of 6 to 12 years, especially their physical and psychomotor skills development. This also holds true for their cognitive as well as social development. In relation to physical development, children around the age of 6 to 8 years will start to learn to control body movements, expanding lots of energy and enjoys manipulating objects, but at this time they may find it challenging to manipulate small objects and performing fine motor skills. However, children around the age of 9-10 years old have different physical characteristics, such as they enjoy being physically active, participating in sport and, dance activities, and is able to do so until they are exhausted (Equitas International Centre for Human Rights Education, 2008).

Based on the explanation above, naturally, children have good control of their bodies and that they are very active. They even tend to be too active which could make them exhausted without realizing it. Therefore, their exercises needs to be controled. Moreover, we need to consider that their activity should be safe for them. One way is to control and stimulate the students to move and do the given exercise by playing suitable music, for example, warming up, main activities and cooling down activities.

Music is commonly used for various activities related to psychomotor. As stated by Ornstein in Ardipal (2010), that psychomotor domain involves various movements and one of them is called Skilled Movements. This includes objectives concerning (1) games, (2) sports, (3) dances, and (4) arts. Music, for example, is used to dance the basic steps of the waltz. Thus music is commonly used in relation to skilled movements. That is why it usually relates with dance and sport. Both of these activities belongs to exercise, as stated by Bates (2006) exercise is part of physical activity and is defined as body movement which is planned, structured, and done repetitive to improve or maintain one or more components of physical fitness.

Moreover, music plays an important role in maintaining motivation to exercise. As stated by Karageorghis and Terry (1997), music has the potential to elicit a small but significant effect on performance especially when athlete are closely matched in ability. . Music is also be an ideal company for exercise, training, and jogging. Karageorghis and Priest (2013) states that empirical research revealed five important ways whereby music can influence performances either during training or competition. These are dissociation, arousal regulation, synchronization, acquisition of motor skills, and attainment of flow.

Firstly, dissociation, is related to a psychological condition that cause by the music to narrow the attention of mind from sensations of fatigue. Therefore, dissociation increases positive mood state, focusing the thoughts away from physiological sensations of fatigue. Although it does not mean that music can increase power, but music is able to lower our attention to exhaustion. Secondly, arousal regulation, is the ability of music to alter emotional and physiological arousal and can be used before competition or training as a stimulant, or as a sedative to control anxious feelings (Bishop et al in Karageorghis \& Priest, 2013). Music that fosters arousal regulation creates optimal mindset toward the athletes performance. Therefore, some athletes use loud music to create good mood and lowers exhaustion, but selections of calmer music can also help to lower down exhaustion. The example of the latter is two-time Olympic gold medalist Kelly Holmes who use soulful ballads by Alicia Keys (e.g., "Fallin"" and "Killing Me Softly") in her pre-event routine at the Athens Games of 2004 (Karageorghis \& Priest, 2013).

Synchronization, is related to music and repetitive exercise. This applies to various sports such as rowing, cycling, cross-country skiing, and running (Karageorghis \& Priest, 2013). Musical tempo regulates movement and it can prolong athletes performance. Synchronizing movements with music enables athletes to perform more efficiently, thus increasing endurance. Karageorghis and Priest (2013) states that music helps acquisition of motor skills. Music has a positive impact on motor skills acquisition. Reminiscing, elementary school physical education is frequently accompanied by music. Music is used to accompany dance and play creating opportunities to explore different tempos of motion and improve coordination. Studies showed that the selection of music can have a positive effect on aesthetic movement in sport (Chen, 1985; Spilthoorn, 1986), however, there is no further and recent research to support this initial findings.

Finally, music influence movements through attainment of flow. Research concerning music's effects on motivational states showed that music may help in the attainment of flow, an important factor for intrinsic motivation. Recent research in sports settings has indeed found that music promotes flow states. Some researchers concluded that interventions including self-selected music and imagery could enhance athletic performance by triggering emotions and cognitions associated with flow. Karageorghis and Deeth (2002)investigated the effects of motivational music on flow during a multistage fitness test. 
Karageorghis et al, (2011) recommended the use of music for sports and exercise. The recomendations are that music should:

(a) be congruent with the socio-cultural background and age group of listeners. Music use must be familiar for example for children, it is better to use national or traditional song with suitable beat.

(b) be functional for the activity. The rhythm and beat should approximate or coordinate with the motor patterns involved in the exercise.

(c) be appropriate with the desired effects in mind. Loud music is more suitable for warming up and main activities while softer, calmer music is suitable for cooling down session.

(d) be selected in consultation with participants. Some form of objective rating method for example, Brunel Music Rating Inventory-2 should be used so that music selection is pleasing to all participants.

(e) be characterised by prominent rhythmic qualities and percussion in addition to pleasing melodic and harmonic structures for repetitive aerobic and anaerobic exercise tasks.

(f) be within the tempo band of 125-140 beats per minute for most healthy people engaged in repetitive, aerobic-type activity (slower music is appropriate for warm-up and cool-down).

(g) be imbued with motivating associations, conditioned either through the media or the personal experiences of the listener.

(h) be accompanied by lyrics with affirmations of movement (e.g., "run to the beat") or generic motivating statements (e.g., "the only way is up").

(i) be used in a safety condition (e.g., patrons should not use music while running or cycling on the roads).

Based on these considerations, not all music, condition, and exercise can be used randomly. Coaches, practitioners and elementary school teachers should choose appropriate music to give the best effect for the students.

Based on the explanation above, it is clear that there are some aspects that are influenced by music if the patrons or athletes plays and listen the music while doing sport. Then, there also some conditions that must be considered in choosing suitable or appropriate music to accompany exercise. Appropriate music and good selection will yield the best result so that the practitioners will have a tendency to get better endurance. Then, what if music is utilized to increase and manage early childhood in doing exercises?

\section{Discussion}

Based on the theory and previous research findings, it shows that music influences the psychological condition of the atheletes. Music also gives a significant effect towards the endurance of athletes during exercises and training. Therefore, it will also give similar effects to the students especially early childhood. Since childhood is in the stage of acquisition of various skills, through music it will enable students to have good acquisition of motor skills. Music will stimulate the students to move based on the beat of the music. Playing music while the students have physical exercise will make them forget their tiredness as music has eliminated their fatigue. And also by using music, we should also manage their exercise in order for the exercise give good effects towards their health condition.

The first step that must be considered is "what kind of music is appropriate for the children?". It is known that different music beats gives different effects to practitioners or students. Thus we need to choose an appropriate music to effectively stimulate them in their exercises. In order to do that, we need to select appropriate music for sports and exercises. Karageorghis, Priest, Terry, Chatzisarantis and Lane (2006) explain that in order to incorporate music into training and competition, the context of the sport should first be considered. The practitioner or teacher need to consider, which type of activity which will be utilized? How does that activity affect the students exercises? What is the desired effect of the given session? What facilities for music are available at school?

Moreover, music is commonly used in various activities related to sport and arts. As stated by Adams in Kid (2007) music helps to improve a student physically (dance helps to increase flexibility, improve circulation, tone the body and develop muscles and also improves posture, balance and coordination), intellectually (dance enriches learning through a variety of perspectives, both traditional and experimental), aesthetically(dance awakens consciousness of beauty, lending new meaning to movement and form), culturally (dance increases understanding and appreciation for forms, choices and rituals from a broad range of historical, social and cultural perspectives), emotionally (dance helps develop self-confidence and self-esteem in a stimulating environment), 
and socially, where it improves sensitivity, understanding, appreciation and consideration for others, both for their similarities and differences.

In Indonesia, it seems that music is only used for dance. Although music, actually had been used for exercises or physical workout since 1984-1996 (Wikipedia, 2013). However, music for exercises is no longer a part of school activities, even exercise activities no longer exists. Physical exercise is only done by playing football, folk games and track running. Meanwhile, music will give a better stimulation for the students to do exercises. As stated by Dorothy in Ardipal (2010:45) that whenever we let a child walk and move based on the music with varios body movements, such as jumping like a frog, creeping like a cat, bending like a snake, and whenever they know. Thus we can make them move along with the music. This activity will be a fun thing for the children. This quote indicates that music can stimulate children to move or do some activities which is categorized as physical exercise. Now, to choose suitable music to accompany students while exercising.

For the second step, physical education teacher must choose ways to deliver the music to the students for their warming up, during the exercise and cooling down activities. Some professional athlete in their training sometime are disturbed by other people's music, therefore, therefore they can use an MP3 player. Some school in the past used music to enhance group cohesion. Thus, it is better to deliver it with a portable hi-fi system. If outside distraction is an important consideration, the volume at which music is played should be set quite high, but not high enough to cause discomfort or leave the ears ringing.

To make exercise better with music means enabling students to tap into the power of music, Karageorghis and Priest (2013) suggest to prepare a wide selection of familiar tracks that meet the following six criteria: (a) strong, energizing rhythm; (b) positive lyrics having associations with movement (c) rhythmic pattern matching the movement patterns of the activity; (d) uplifting melodies and harmonies; (e) associations with sport, exercise, triumph, or overcoming adversity; and (f) a musical style or idiom suited to an athlete's taste and cultural upbringing. Choose tracks with different tempo, to effectively coincide with low, medium, and high-intensity exercise.

A further consideration is diversity of music selections. A study from a major fitness chain in the United Kingdom (Priest, Karageorghis, \& Sharp, 2004) indicated that diversity in the selections is paramount. Table 1 presents titles of motivational tracks suitable for different components of a single training session with a specific individual in mind.

Table 1. Example motivational music for training-session components of different exercise intensities

\begin{tabular}{lllc}
\hline \multicolumn{1}{c}{ Workout Component } & \multicolumn{1}{c}{ Title } & \multicolumn{1}{c}{ Artist(s) } & $\begin{array}{c}\text { Tempo, in Beats per } \\
\text { Minute }\end{array}$ \\
\hline Mental preparation & "Umbrella" & Rihanna Ft. Jay Z & 89 \\
Warm-up activity & "Getting' Jiggy With It" & Will Smith & 108 \\
Stretching & "Lifted" & The Lighthouse Family & 98 \\
Strength component & "Funky Cold Medina" & Tone Loc & 118 \\
Endurance component & "Rockafeller Skank (Funk Soul & Fatboy Slim & 153 \\
& Brother)" & & \\
Cool-down activity & "Whatta Man" & Salt-n-Pepa & 88 \\
\hline
\end{tabular}

Source: Karageorghis \& Priest, 2013

However, the examples above might not be acceptable or appropriate for the children in relation to the lyric, their preference and background. In Indonesia, some national music can be used, such as "Bangun Pemuda" can be used for mental preparation activity or running. Other local or traditional songs can also be used in exercises such as Jali Jali (Jakarta) or Tanduk Majeng (East Java) for mental preparation These songs will stimulate the students with soft body movement which would prepare them for higher beat exercise.

Then followed by warm-up activity, with songs like Yamko Rambe Yamko (Papua), Cing Cangkeling (West Java), Rasa Sayange (Maluku), and Paris Barantai (South Kalimantan).. This will stimulate them to move and increase their motivation. Finally, to slow down or streching, choose musics with slow beat. Some music that can be used, such as Poco-Poco (Celebes) and Sajojo (Papua). This songs have tempo which varies from 88-152 beat per 
minutes.

In activities such as running or jogging can be also accompanied with music. Sometimes, children feel tired after running around the soccer field, music can help them keep their spirit to continue on by finding suitable music which match the beat of the heart. The faster the beat the higher the students motivation. Slower beat is suitable for stretching activities. Therefore, a sound system should be available to accompany students during exercising.

\section{Conclusion}

There are various ways where music can be used for elementary school students during physical education classes. The effects of carefully selected music are both quantifiable and meaningful. Research findings have found the possibility of using music during athletic performance may yield long-term benefits such as exercise adherence and heightened sports performance, through a superior quantity and quality of training (Karageorghis \& Priest, 2013). Although many athletes today use music during exercising, not many research focus its relation to childrens' physical activities. We hope that through applying the principles outlined in this article, researchers and teachers can stimulate and enhances the effects of music with greater precision.

\section{References}

Ardipal. (2010). Pengembangan Model Pembelajaran Seni di Sekolah Dasar (unpublish dissertation). Padang: Post Graduate Program of Universitas Negeri Padang.

Bates, H. (2006). Daily Physical Activity for Children and Youth. Alberta: Alberta Education.

Chen, P. (1985). Music as a stimulus in teaching motor skills. New Zealand Journal of Health, Physical Education and Recreation, 18, 19-20.

Equitas International Centre for Human Rights Education. (2008). Play it Fair Tool Kit. Retrieved from



Karageorghis, C. I., \& Deeth, I. P. (2002). Effects of motivational and oudeterous asynchronous music on perceptions of flow. Journal of Sports Sciences, 20, 66-67.

Karageorghis, C. I., \& Priest, D. L. (2013). Music in Sport and Exercise: An Update on Research and Application. Sport Journal. Retrieved September 22, 2013, from http://thesportjournal.org/article/music-sport-and-exercise-update-research-and-application

Karageorghis, C. I., \& Terry, P. C. (1997). The psychophysical effects of music in sport and exercise: A review. Journal of Sport Behavior, 20, 54-68.

Karageorghis, C. I., Priest, D. L., Terry, P. C., Chatzisarantis, N. L. D., \& Lane, A. M. (2006). Redesign and initial validation of an instrument to assess the motivational qualities of music in exercise: The Brunel Music Rating Inventory-2. Journal of Sports Sciences, 24, 899-909. http://dx.doi.org/10.1080/02640410500298107

Karageorghis, C. I., Terry, P. C., Lane, A. M., Priest, D. L., Bishop, D. T., \& Lee, J. (2011). The BASES Expert Statement on the Use of Music in Exercise. The Sport and Exercise Scientist, 28, 18-19.

Spilthoorn, D. (1986). The effect of music on motor learning. Bulletin de la Federation Internationale de l'Education Physique, 56, 21-29.

Wikipedia. (n. d.). Senam Kesegaran Jasmani. Retrieved September 18, 2013, from http://id.wikipedia.org/wiki/Senam_Kesegaran_Jasmani

\section{Copyrights}

Copyright for this article is retained by the author(s), with first publication rights granted to the journal.

This is an open-access article distributed under the terms and conditions of the Creative Commons Attribution license (http://creativecommons.org/licenses/by/3.0/). 